\title{
Electrochemical, Kinetic, Antimicrobial (MIC) Studies of Acyclic Schiff-Base Nickel(II) Complexes
}

\author{
S. PRAVEEN KUMAR ${ }^{\mathrm{a}}$, A.VIJAYARAJ ${ }^{\mathrm{a}}$, L. VIJAYALAKSHMI $^{\mathrm{b}}$ and V. NARAYANAN ${ }^{\mathrm{a}}$ \\ ${ }^{a}$ Department of Inorganic Chemistry, University of Madras, Guindy Campus, \\ Chennai-600025, India \\ bVidhya Sagar Women's College, Chengalpattu, Kancheepuram-603211, India \\ vnnara@yahoo.co.in
}

Received 19 January 2013 / Accepted 15 February 2013

\begin{abstract}
A series of acyclic mononuclear nickel(II) complexes have been prepared by Schiff base condensation derived from 5-bromosalicylaldehyde, diethylenetriamine, tris(2-aminoethyl) amine, triethylenetetramine, $N, N$-bis(3-aminopropyl)ethylene diamine, $N, N$-bis(aminopropyl) piperazine, nickel perchlorate. Electronic spectra of nickel(II) complexes show d-d transition in the range of $780-920 \mathrm{~nm}$. Electrochemical studies of the nickel(II) complexes show irreversible one electron reduction, oxidation process. The reduction potential of the mononuclear nickel(II) complexes shifts towards anodic direction and oxidation potential shift towards to more cathodic direction upon increasing the chain length of the imine compartment. Electrochemical and catalytic studies of the complexes were compared on the basis of increasing the chain length of the imine compartment. All the complexes were screened for antifungal and antibacterial activity. Nickel is recognized as an essential trace element for bacteria, plants and animals. The active sites of enzymes such as urease, carbon monoxide dehydrogenase, [NiFe]-hydrogenase and methyl-S-coenzyme-M methylreductase are known to contain nickel centres, which are intimately involved in the catalytic cycles.
\end{abstract}

Keywords: Electrochemical, Kinetics, Antimicrobial studies, Acyclic Schiff-Base

\section{Introduction}

There has been a considerable effort in recent years towards the preparation of new Schiff base synthesized from the reaction of dialdehydes and amino compounds ${ }^{1}$. New Schiff base macroligands have been synthesized to study their selectivity towards complexation of metal ions. Schiff bases containing acyclic and cyclic imine bonds are of great importance in modern coordination chemistry ${ }^{2}$. Metal complexes of these ligands are widely used as luminescent complexes $^{3}$, liquid crystal $^{4}$ structures, chemosensors ${ }^{5}$ and other useful metal-containing azomethine compounds ${ }^{6}$. Many transition metal ions in living systems work as enzymes or carriers in a macrocyclic ligand environment. Meaningful research in this direction might generate simple models for biologically occurring metalloenzymes ${ }^{7}$ and thus help in further understanding biological systems. Nickel is recognized as an essential trace element for bacteria, plants and animals ${ }^{8}$. The active sites of enzymes such as urease, carbon monoxide dehydrogenase, $[\mathrm{NiFe}]$-hydrogenase and methyl-S-coenzyme-M methylreductase are known to contain nickel centers, which are intimately involved in the catalytic cycles ${ }^{9}$.

\footnotetext{
$\dagger$ Presented to the National Conference on Chemistry Solutions at SRM University, India
} 


\section{Experimental}

Elemental Analysis of the complexes is obtained using a Haereus CHN rapid analyzer. Conductivity measurement of the complexes is obtained using a Elico digital conductivity bridge modal CM-88 using freshly prepared solution of the complex in DMF. IR spectra were recorded on a PerkinElmer FT-IR 8300 series spectrophotometer on $\mathrm{KBr}$ disks from 4000 to $400 \mathrm{~cm}^{-1}$. ${ }^{1} \mathrm{H}$ NMR spectra were recorded using a BRUKER GSX 300MHz NMR spectrometer. Mass spectra were obtained on a JEOL DX-303 mass spectrometer. Electronic spectral studies were carried out on a PerkinElmer 320 spectrophotometer from 200 to $1100 \mathrm{~nm}$. Cyclic voltammograms were obtained on a CHI-600A electrochemical analyzer under oxygen-free conditions using a three-electrode cell in which a glassy carbon electrode was the working electrode, a saturated $\mathrm{Ag} / \mathrm{AgCl}$ electrode was the reference electrode and platinum wire was the auxiliary electrode. A ferrocene/ ferrocenium couple was used as an internal standard and $E_{1 / 2}$ of the ferrocene/ ferrocenium $\left(\mathrm{Fc} / \mathrm{Fc}^{+}\right)$couple under the experimental condition was $470 \mathrm{mV}$. Tetra( $n$-butyl)ammonium perchlorate (TBAP) was used as the supporting electrolyte. Room temperature magnetic moments were measured on a PAR vibrating sample magnetometer Model-155. X-band EPR spectra were recorded at $25{ }^{\circ} \mathrm{C}$ on a Varian EPR-E 112 spectrometer using diphenylpicrylhydrazine (DPPH) as the reference. Catalytic oxidation of catechol to oquinone by the copper complexes was studied in $10^{-3} \mathrm{M}$ dimethylformamide solutions. The reactions were followed spectrophotometrically with the strongest absorption band of $o$-quinone at $390 \mathrm{~nm}$ and monitoring the increase in absorbance. A plot of $\log \left(\mathrm{A}_{\infty} / \mathrm{A}_{\infty}-\mathrm{A}_{\mathrm{t}}\right)$ $v s$. time was made for each complex and the rate constant for the catalytic oxidations were calculated.

\section{Chemicals and reagent}

5-Bromosalicylaldehyde was purchased from Sigma-Aldrich. Analytical grade ethanol, acetonitrile, and DMF were purchased from Qualigens. TBAP, used assupporting electrolyte in electrochemical measurements, was purchased from Fluka and recrystallized from hot methanol. $N, N$-bis-(3-aminopropyl) piperazine, $N, N$-bis-(3-aminopropyl) ethylene diamine and tris-(2-aminoethyl)amine were purchased from Aldrich. Triethylenetetramine and diethylenetriamine were purchased from Qualigens.

\section{Microorganisms}

The test bacterial strains Pseudomonas aeruginosa, E.coli, Candida albicans and Salmonella typhii were obtained from the Department of Microbiology, SRM Medical University, Chennai, Tamil Nadu was isolated clinically. The test organisms were sub-cultured at $37^{\circ} \mathrm{C}$ and maintained on nutrient agar media.

\section{Disc diffusion method}

The bacterial inoculum was uniformly spread using sterile glass rod on a sterile Petri dish containing Nutrient Agar. Five concentrations of 25, 50, 75, 100 and $125 \mu \mathrm{M}$ of pure substances were prepared in DMSO. The test substances of $50 \mu \mathrm{L}$ were added to each of the 5 wells $(7 \mathrm{~mm}$ diameter holes cut in the agar gel, $20 \mathrm{~mm}$ apart from one another). The systems were incubated for $24 \mathrm{~h}$ at $36^{\circ} \mathrm{C} \pm 1^{\circ} \mathrm{C}$, under aerobic conditions. After incubation, confluent bacterial growth was observed. Inhibition of the bacterial growth was measured in $\mathrm{mm}$. Tests were performed in duplicate, whose minimum inhibitory concentration (MIC) values are provided in centimeters $(\mathrm{cm})$ in diameter. 


\section{General synthesis of ligands}

Synthesis of (9E)- $N^{1}-(2-h y d r o x y-5-b r o m o b e n z y l i d e n e)-N^{2}-((E)-2-(2-h y d r o x y-5-b r o m o$ benzylideneamino)ethyl)ethane-1,2-diamine $\left[L^{1}\right]$

An absolute methanol solution $(10 \mathrm{~mL})$ containing diethylenetriamine $(0.1030 \mathrm{~g}, 1 \mathrm{mmol})$ was added drop-wise to a stirred solution of 5-bromosalicylaldehyde $(0.4020 \mathrm{~g}, 2 \mathrm{mmol})$. The solution was refluxed for 8 hours the above reaction shown in Scheme 1. The resulting yellow solution was cooled in ice. The yellow precipitate formed was filtered and washed with hexane and dried under vacuum. The crude product on recrystallization from THF gave yellow crystals.

Yield (53.8\%). M.p.: $156^{\circ} \mathrm{C}$. Anal. For Analy. For $\mathrm{C}_{18} \mathrm{H}_{19} \mathrm{Br}_{2} \mathrm{~N}_{3} \mathrm{O}_{2}$; Calcd(\%): C, 46.08; H, 4.08; N, 8.96; Found C, 46.04; H, 4.05; N, 8.91; ESI MS: $(\mathrm{m} / \mathrm{z}) 467.19\left[\mathrm{MH}^{+}\right]$. Calcd av. $\mathrm{m} / z$ 466.98. IR data, $(\mathrm{KBr})\left(\mathrm{v}, \mathrm{cm}^{-1}\right): 3385 v[\mathrm{~b},(\mathrm{OH})], 1625[\mathrm{~s}, \mathrm{v}(\mathrm{C}=\mathrm{N})],{ }^{1} \mathrm{H}$ NMR $(\mathrm{ppm}$ in $\left.\mathrm{CDCl}_{3} 300 \mathrm{MHz}\right): \delta 2.93(\mathrm{t}, 2 \mathrm{H}, \mathrm{J}=5.4 \mathrm{~Hz}), 3.65(\mathrm{t}, 2 \mathrm{H}, \mathrm{J}=5.4 \mathrm{~Hz}), 6.74-7.32(\mathrm{~m}, 3 \mathrm{H})$, $8.21(\mathrm{~s}, 1 \mathrm{H}), 13.27(\mathrm{~s}, 1 \mathrm{H}) .{ }^{13} \mathrm{C} \mathrm{NMR}\left(\mathrm{CDCl}_{3}, 300 \mathrm{MHz}\right): \delta 46.31,53.21,117.27,119.52$, 126.28, 138.71, 139.11, 161.71, 162.31.

Ligands $\mathrm{L}^{2}, \mathrm{~L}^{3}, \mathrm{~L}^{4}$ and $\mathrm{L}^{5}$ were synthesized by following the above procedure using tris(2-aminoethyl)amine $(0.1490 \mathrm{~g}, 1 \mathrm{mmol})$, triethylenetetramine $(0.1420 \mathrm{~g}, 1 \mathrm{mmol}), N, N$-bis(3-aminopropyl)ethylenediamine $(0.1740 \mathrm{~g}, 1 \mathrm{mmol})$ and $N, N$-bis-(3-aminopropyl)piperazine $(0.2000 \mathrm{~g}, 1 \mathrm{mmol})$ respectively instead of diethylenetriamine.

Synthesis of $N^{I}, N^{I}$-bis((E)-2-(2-hydroxy5-bromobenzylideneamino)ethyl)ethane-1,2diamine $\left[L^{2}\right]$

Yield (33.2\%). M.p.: $148{ }^{\circ} \mathrm{C}$. Anal. For $\mathrm{C}_{20} \mathrm{H}_{24} \mathrm{Br}_{2} \mathrm{~N}_{4} \mathrm{O}_{2}$;Calcd (\%): C, 46.89; H, 4.72; N, 10.94; Found C, 46.87; H, 4.70; N, 10.92; ESI MS: $(\mathrm{m} / \mathrm{z})$ 510.03Calcd av. $\mathrm{m} / \mathrm{z} 512.24$ selected IR data $(\mathrm{KBr})\left(\mathrm{v}, \mathrm{cm}^{-1}\right): 3471[\mathrm{~b}, \mathrm{v}(\mathrm{OH})], 1632[\mathrm{~s}, \mathrm{v}(\mathrm{C}=\mathrm{N})],{ }^{1} \mathrm{H}$ NMR (ppm in $\mathrm{CDCl}_{3}$ $300 \mathrm{MHz}): \delta 2.07(\mathrm{~s}, 2 \mathrm{H}), 2.5-12.59(\mathrm{~m}, 8 \mathrm{H}), 3.71(\mathrm{~m}, 4 \mathrm{H}), 8.32(\mathrm{~s}, 2 \mathrm{H}), 6.53-7.80(\mathrm{~m}, 6 \mathrm{H})$, $8.14(\mathrm{~s}, 2 \mathrm{H}) .{ }^{13} \mathrm{C} \mathrm{NMR}\left(\mathrm{CDCl}_{3}, 300 \mathrm{MHz}\right): \delta 39.23,52.57,58.14,59.03,117.08,118.32$, 126.07, 133.75, 137.07, 163.13, 164.41.

Synthesis of (9E)- $N^{l}-(2-((E)-2-(2-h y d r o x y-5-b r o m o b e n z y l i d e n e a m i n o)$ ethylamino $)$ ethyl)- $N^{2}-(2-h y d r o x y-5-b r o m o b e n z y l i d e n e)$ ethane-1,2-diamine $\left[L^{3}\right]$

Yield (39.5\%). M.p.: $135{ }^{\circ} \mathrm{C}$. Anal.for $\mathrm{C}_{20} \mathrm{H}_{24} \mathrm{Br}_{2} \mathrm{~N}_{4} \mathrm{O}_{2}$;Calcd (\%): C, 46.89; H, 4.72; N, 10.94; Found C, 46.86; H, 4.68; N, 10.92; ESI MS: $(\mathrm{m} / \mathrm{z}) 510.03\left[\mathrm{MH}^{+}\right]$. Calcd av. $\mathrm{m} / \mathrm{z}$ 512.67. Selected IR data $(\mathrm{KBr})\left(v, \mathrm{~cm}^{-1}\right): 3443 v(\mathrm{OH}), 1620[\mathrm{~s}, v(\mathrm{C}=\mathrm{N})],{ }^{1} \mathrm{H}$ NMR (ppm in $\left.\mathrm{CDCl}_{3} 300 \mathrm{MHz}\right): \delta 2.94-3.02(\mathrm{~m}, 4 \mathrm{H}), 3.41-3.47(\mathrm{~m}, 4 \mathrm{H}), 2.67-2.86(\mathrm{~m}, 4 \mathrm{H}), 6.64-$ $7.41(\mathrm{~m}, 6 \mathrm{H}), 7.41(\mathrm{~s}, 2 \mathrm{H}), 13.17(\mathrm{~s}, 2 \mathrm{H}):{ }^{13} \mathrm{C} \mathrm{NMR}\left(\mathrm{CDCl}_{3}, 300 \mathrm{MHz}\right): \delta 49.70,52.93$, $58.35,110.73,115.43,130.21,137.23,138.61,163.26,164.14$.

Synthesis of (9E)-N $N^{I}-(2-((E)-3-(2-h y d r o x y-5-$ bromobenzylideneamino)propylamino $)$ ethyl)- $N^{3}-(2,5$-dibromobenzylidene $)$ propane-1,3-diamine $\left[L^{4}\right]$

Yield (31.5\%). M.p.: $140{ }^{\circ} \mathrm{C}$. Anal. For $\mathrm{C}_{22} \mathrm{H}_{28} \mathrm{Br}_{2} \mathrm{~N}_{4} \mathrm{O}_{2}$;Calcd (\%): C, 48.91; H, 5.22; N, 10.37; Found C, 48.88; H, 5.20; N, 10.34; ESI MS: $(\mathrm{m} / \mathrm{z})$ 541.30, Calcd av. $\mathrm{m} / \mathrm{z}$, 540.29 selected IR data $(\mathrm{KBr})\left(v, \mathrm{~cm}^{-1}\right): 3465 v(\mathrm{OH}), 1630[\mathrm{~s}, v(\mathrm{C}=\mathrm{N})] .{ }^{1} \mathrm{H}$ NMR $\left(\mathrm{ppm}\right.$ in $\mathrm{CDCl}_{3}$ $300 \mathrm{MHz}): \delta 1.71-1.78(\mathrm{~m}, 4 \mathrm{H}), 2.53-2.67(\mathrm{~m}, 4 \mathrm{H}) 2.13-2.24(\mathrm{~m}, 4 \mathrm{H}), 3.48(\mathrm{t}, 4 \mathrm{H}, \mathrm{J}=6.2$ $\mathrm{Hz}), 6.63-7.82(\mathrm{~m}, 6 \mathrm{H}), 8.44(\mathrm{~s}, 2 \mathrm{H}), 8.12(\mathrm{~s}, 2 \mathrm{H}), 12.41(\mathrm{~s}, 2 \mathrm{H}){ }^{13} \mathrm{C} \mathrm{NMR}\left(\mathrm{CDCl}_{3}, 300 \mathrm{MHz}\right)$ : $32.17,37.27,38.17,116,62,127.13,132.51,136.43,163.21,165.11$. 
Synthesis of (9E)-N-(2-hydroxy-5-bromobenzylidene)-3-(4-((E)-3-(2-hydroxy-5bromobenzylideneamino)propyl)piperazin-1-yl)propan-1-amine $\left[L^{5}\right]$

Yield (34.5\%). m.p.: $145{ }^{\circ} \mathrm{C}$. Anal. for $\mathrm{C}_{24} \mathrm{H}_{30} \mathrm{Br}_{2} \mathrm{~N}_{4} \mathrm{O}_{2}$;Calcd (\%): C, 50.90; H, 5.34; N, 9.89; Found :C, 50.87; H, 5.32; N, 9.87; ESI MS: $(\mathrm{m} / z) 563.33 \mathrm{Calcd}$ av. $\mathrm{m} / \mathrm{z} 566.33$ selected IR data $(\mathrm{KBr})\left(v, \mathrm{~cm}^{-1}\right): 3465 \mathrm{v}(\mathrm{OH}), 1622[\mathrm{~s}, \mathrm{v}(\mathrm{C}=\mathrm{N})] .{ }^{1} \mathrm{H}$ NMR $\left(\mathrm{ppm}\right.$ in $\left.\mathrm{CDCl}_{3} 300 \mathrm{MHz}\right)$ :

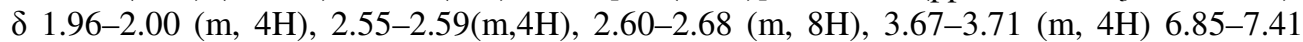
$(\mathrm{m}, 6 \mathrm{H}), 13.48(\mathrm{~s}, 2 \mathrm{H})\left(\mathrm{CDCl}_{3}, 300 \mathrm{MHz}\right): \delta 29.42,52.63,55.23,68.71,118.23,119.28$, $128.23,132.21,137.82,157.33,159.92$.

\section{Synthesis of nickel complex}

\section{Synthesis of mono nuclear [Ni(II)L $\left.{ }^{1}\left(\mathrm{ClO}_{4}\right)\right]$ complex}

An absolute methanol solution containing $\mathrm{Ni}\left(\mathrm{ClO}_{4}\right)_{2} \cdot 6 \mathrm{H}_{2} \mathrm{O}(0.0365 \mathrm{~g}, 0.1 \mathrm{mmol})$ was added drop wise to a stirring solution of $\mathrm{L}^{1}(0.0466 \mathrm{~g}, 0.1 \mathrm{mmol})$ in $20 \mathrm{~mL}$ of absolute methanol. The solution was refluxed for 8 hours the above reaction shown in Scheme 2. On cooling the solution yellow color microcrystals are formed, which were filtered and washed with methanol followed by diethyl ether and dried in vacuum. The crude product was recrystallized from methanol and acetonitrile $(1: 3, \mathrm{v} / \mathrm{v})$. [ $\left.\mathrm{Ni}(\mathrm{II}) \mathrm{L}^{2}\right],\left[\mathrm{Ni}(\mathrm{II}) \mathrm{L}^{3}\right],\left[\mathrm{Ni}(\mathrm{II}) \mathrm{L}^{4}\right]$ and $\left[\mathrm{Ni}(\mathrm{II}) \mathrm{L}^{5}\right]$ were synthesis by following the above procedure using $\mathrm{L}^{2}(0.0512 \mathrm{~g}, 0.1 \mathrm{mmol}), \mathrm{L}^{3}(0.0512 \mathrm{~g}$, $0.1 \mathrm{mmol}), \mathrm{L}^{4}(0.0540 \mathrm{~g}, 0.1 \mathrm{mmol})$ and $\mathrm{L}^{5}(0.0566 \mathrm{~g}, 0.1 \mathrm{mmol})$ ligands (Scheme 1).

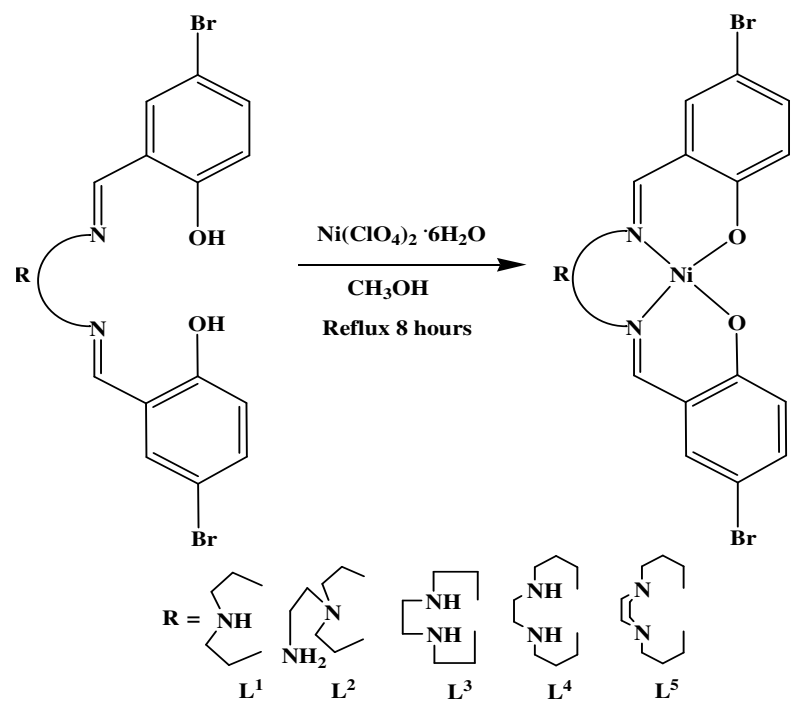

Scheme 1

Yield: (59\%) m.p.:321 ${ }^{\circ} \mathrm{C}$ (dec). Anal.for $\mathrm{C}_{18} \mathrm{H}_{16} \mathrm{Br}_{2} \mathrm{ClN}_{3} \mathrm{O}_{6} \mathrm{Ni}$; Calcd (\%): C, 34.63; H, 2.58; N, 6.73; Ni, 9.40; Found (\%): C, 34.60; H, 2.56; N, 6.71; Ni, 9.38; ESI Mass: $(\mathrm{m} / \mathrm{z}$ 622.84 Calcd av. $m / z$ 624.29). Conductance $\left(\Lambda \mathrm{Scm}^{2} \mathrm{~mol}^{-1}\right)$ in DMF: 129 . Selected IR data $(\mathrm{KBr})\left(v, \mathrm{~cm}^{-1}\right): 3360 \mathrm{~b}\left[v\left(\mathrm{~N}-\mathrm{CH}_{2}\right)\right], 1634 \mathrm{~s}[\mathrm{v}(\mathrm{C}=\mathrm{N})], 1087 \mathrm{w}\left[v\left(\mathrm{ClO}_{4}^{-}\right)\right.$coordinated], $611 \mathrm{~s}$ [v (M-N)], $430 \mathrm{~m}[v(\mathrm{M}-\mathrm{O})]$.

\section{Synthesis of [Ni(II)L $\left.L^{2}\right]$ Complex}

Yield: (66\%) m.p.:284 ${ }^{\circ} \mathrm{C}$ (dec). Anal.for $\mathrm{C}_{20} \mathrm{H}_{22} \mathrm{Br}_{2} \mathrm{~N}_{4} \mathrm{O}_{2} \mathrm{Ni}$; Calcd (\%):C, 42.30; H, 3.73;N, 9.87; Ni, 10.34; Found (\%):C, 42.28; H, 3.71;N, 9.86; Ni, 10.32;ESI Mass: (m/z 565.96 Calcd 
av. $m / z$ 568.92). Conductance $\left(\Lambda \mathrm{Scm}^{2} \mathrm{~mol}^{-1}\right)$ in DMF: 55. Selected IR data $(\mathrm{KBr})\left(v, \mathrm{~cm}^{-1}\right)$ : $3173 v\left(\mathrm{~N}-\mathrm{CH}_{2}\right), 1623[\mathrm{~s}, v(\mathrm{C}=\mathrm{N})], 629[\mathrm{~s}, v(\mathrm{M}-\mathrm{N})], 482[\mathrm{~s}, v(\mathrm{M}-\mathrm{O})]$.

Synthesis of $\left[\mathrm{Ni}(\mathrm{II}) \mathrm{L}^{3}\right]$ complex

Yield: (52\%) m.p.:225 ${ }^{\circ} \mathrm{C}$ (dec). Anal.for $\mathrm{C}_{20} \mathrm{H}_{20} \mathrm{Br}_{2} \mathrm{~N}_{4} \mathrm{O}_{2} \mathrm{Ni}$; Calcd (\%): C, 42.37; H, 3.56; $\mathrm{N}, 9.88$; Ni, 10.35; Found (\%): C, 42.34; H, 3.54; N, 9.86; Ni, 10.32; ESI Mass: $(\mathrm{m} / \mathrm{z}$ 564.94Calcd av. $\mathrm{m} / z$ 566.90). Conductance $\left(\Lambda \mathrm{Scm}^{2} \mathrm{~mol}^{-1}\right)$ in DMF: 59. Selected IR data $(\mathrm{KBr})\left(v, \mathrm{~cm}^{-1}\right): 3224 v\left(\mathrm{~N}-\mathrm{CH}_{2}\right), 1636$ [s, v(C=N)], 598 [s, v (M-N)], 467 [s, v (M-O)].

\section{Synthesis of $\left[\mathrm{Ni}(\mathrm{II}) \mathrm{L}^{4}\right]$ complex}

Yield: (57\%) m.p.:224 ${ }^{\circ} \mathrm{C}$ (dec). Anal.for $\mathrm{C}_{22} \mathrm{H}_{24} \mathrm{Br}_{2} \mathrm{~N}_{4} \mathrm{O}_{2} \mathrm{Ni}$; Calcd (\%): C, 44.41; H, 4.07; N, 9.42; Ni, 9.87; Found (\%): C, 44.39; H, 4.00;N, 9.40; Ni, 9.86; ESI Mass: ( $\mathrm{m} / \mathrm{z}$ 592.93 Calcd av. $\mathrm{m} / z$ 594.95). Conductance $\left(\Lambda \mathrm{Scm}^{2} \mathrm{~mol}^{-1}\right)$ in DMF: 51. Selected IR data $(\mathrm{KBr})\left(v, \mathrm{~cm}^{-1}\right)$ : $3119 v\left(\mathrm{~N}-\mathrm{CH}_{2}\right), 1629[\mathrm{~s}, v(\mathrm{C}=\mathrm{N})], 589[\mathrm{~s}, v(\mathrm{M}-\mathrm{N})], 488[\mathrm{~s}, v(\mathrm{M}-\mathrm{O})]$.

Synthesis of $\left[N i(I I) L^{5}\right]$ complex

Yield: (54\%) m.p.: $225{ }^{\circ} \mathrm{C}$ (dec). Anal.for $\mathrm{C}_{24} \mathrm{H}_{28} \mathrm{Br}_{2} \mathrm{~N}_{4} \mathrm{O}_{2} \mathrm{Ni}$; Calcd (\%):C, 46.27; H, 4.53; $\mathrm{N}, 8.99$; Ni, 9.42; Found (\%):C, 46.25; H, 4.52; N, 8.97; Ni, 9.40; ESI Mass: $(\mathrm{m} / \mathrm{z}$ 621.93Calcd av. $\mathrm{m} / z$ 623.01).Conductance $\left(\Lambda \mathrm{Scm}^{2} \mathrm{~mol}^{-1}\right)$ in DMF: 56. Selected IR data $(\mathrm{KBr})\left(v, \mathrm{~cm}^{-1}\right): 3134 v\left(\mathrm{~N}-\mathrm{CH}_{2}\right), 1635$ [s, v(C=N)], 597 [s, v (M-N)], 487 [s, v (M-O)].

\section{Results and Discussion}

\section{FT IR spectral analysis}

The FT IR spectrum of the precursor compound (PC) shows a sharp band at around $1668 \mathrm{~cm}^{-1}$ due to the presence of $\mathrm{CHO}$ group. The $\mathrm{OH}$ group in the ligand shows a broad peak at $3378 \mathrm{~cm}^{-1}$. All the ligands show a band at $3389 \mathrm{~cm}^{-1}$ due to the phenolic and aliphatic $\mathrm{OH}$ groups. The band in the region of $1636-1590 \mathrm{~cm}^{-1}$ in the ligands is due to the presence of imine $(\mathrm{C}=\mathrm{N})$ group. All the complexes show a sharp band in the region $1636-1620 \mathrm{~cm}^{-1}$, due to $v(\mathrm{C}=\mathrm{N})$ stretching. The complete disappearance of aldehydic group of the precursor and the appearance of imine $(\mathrm{CH}=\mathrm{N}-)$ group in the ligands show the effective Schiff base condensation between the aldehyde group of the precursor compound and the amine groups ${ }^{10}$. For the complexes, bands at $460-490 \mathrm{~cm}^{-1}$ could be assigned to $-\mathrm{M}-\mathrm{O}$ bond. Other weak bands at lower frequency could be assigned to $-\mathrm{M}-\mathrm{N}$ bond ${ }^{11}$. The spectra of all the complexes are dominated by bands at $3150-3070 \mathrm{~cm}^{-1}$ due to the aromatic C-H stretching vibration. A strong band at $1260 \mathrm{~cm}^{-1}$ in the free Schiff bases has been assigned to phenolic $\mathrm{C}-\mathrm{O}$ stretching vibration. Upon complexation, this band shifts to higher frequency $\left(1300 \mathrm{~cm}^{-1}\right)$ showing coordination through phenolic oxygen ${ }^{12}$. The presence of uncoordinated perchlorate anions in all of the mononuclear complexes are inferred from a single broad band around $1100 \mathrm{~cm}^{-1}$ ( $v_{3}$-antisymmetric stretching) which are not split and a band around $650 \mathrm{~cm}^{-1}$ ( $v_{4}$-antisymmetric bending). The band around $930 \mathrm{~cm}^{-1}\left(v_{2}\right.$ - symmetric stretching) due to coordinated perchlorate is not observed and this indicates that no perchlorate ions are coordinated in the complexes.

\section{Electronic spectra}

Electronic spectra of all the complexes were obtained in DMF medium. The electronic absorption spectra of $\mathrm{Ni}(\mathrm{II})$ complexes are recorded at $25{ }^{\circ} \mathrm{C}$ and the absorption region assignment data are given in Table 1 and the proposed geometry of the complexes are given. 


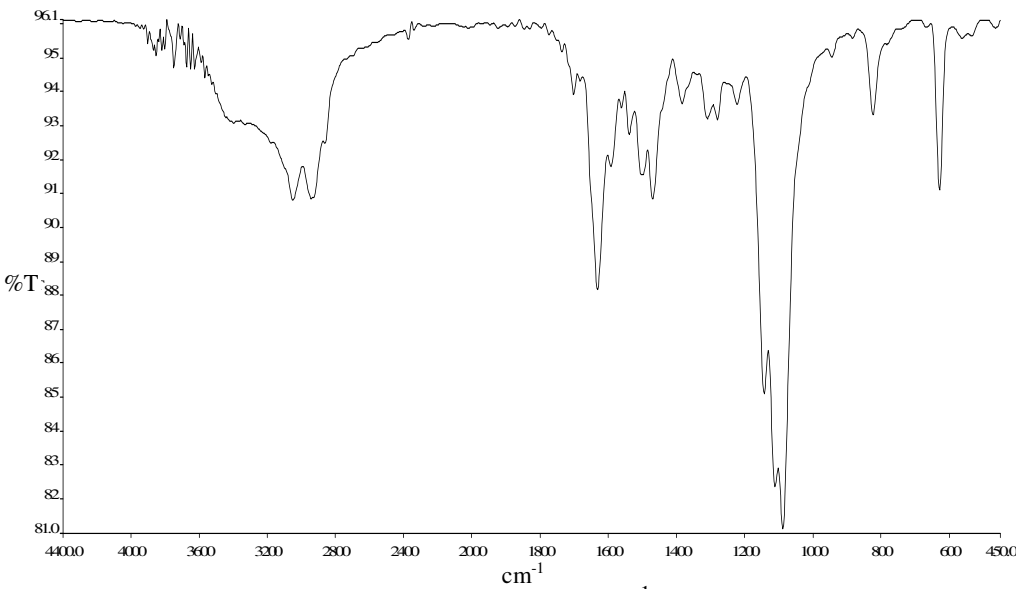

Figure 1. FT IR spectrum of: $\left[\mathrm{NiL}^{1}\left(\mathrm{ClO}_{4}\right)\right]$ complex

Table 1. Electronic spectral data of acyclic mononuclear $\left[\mathrm{Ni}(\mathrm{II}) \mathrm{L}^{1-5}\right]$ complexes

\begin{tabular}{|c|c|c|c|c|}
\hline Sl. No. & Complexes & \multicolumn{3}{|c|}{$\lambda_{\max }, \mathrm{nm}, \varepsilon / \mathrm{M}^{-1} \mathrm{~cm}^{-1}$} \\
\hline & & $d-d$ & Charge & transfer \\
\hline 1. & {$\left[\mathrm{Ni}(\mathrm{II}) \mathrm{L}^{1}\left(\mathrm{ClO}_{4}\right)\right]$} & $780(125)$ & $330(19409)$ & 305 (21342) \\
\hline 2. & {$\left[\mathrm{Ni}(\mathrm{II}) \mathrm{L}^{2}\right]$} & $791(123)$ & $335(19335)$ & $302(21287)$ \\
\hline 3. & {$\left[\mathrm{Ni}(\mathrm{II}) \mathrm{L}^{3}\right]$} & $825(116)$ & $370(16965)$ & $280(22654)$ \\
\hline 4. & {$\left[\mathrm{Ni}(\mathrm{II}) \mathrm{L}^{4}\right]$} & $843(109)$ & $375(16841)$ & $270(24137)$ \\
\hline 5. & {$\left[\mathrm{Ni}(\mathrm{II}) \mathrm{L}^{5}\right]$} & $920(96)$ & $386(16221)$ & $267(24272)$ \\
\hline
\end{tabular}

The electronic spectra of $[\mathrm{Ni}(\mathrm{II}) \mathrm{L}]$ complexes show a single weak d-d band in region 780-832 nm due to ${ }^{3} \mathrm{~A}_{2} \rightarrow{ }^{3} \mathrm{~T}_{2}(\mathrm{~F}),{ }^{3} \mathrm{~T}_{1}(\mathrm{~F})$ associated with distorted octahedral geometry ${ }^{13}$. A red shift in the $\lambda_{\max }$ value of $\mathrm{d}-\mathrm{d}$ band ${ }^{14}$ with increase in the chain length between imine nitrogen has been observed. This red shift may be due to the distortion from planar geometry as the chain length increases. Moderately intense band observed in the region of 365-385 nm is associated with ligand to metal charge transfer transition. An intense band observed in the region 280-305 $\mathrm{nm}$ is associated with intra ligands transition. The electronic absorption spectra are given in Figure $2 \& 3$.

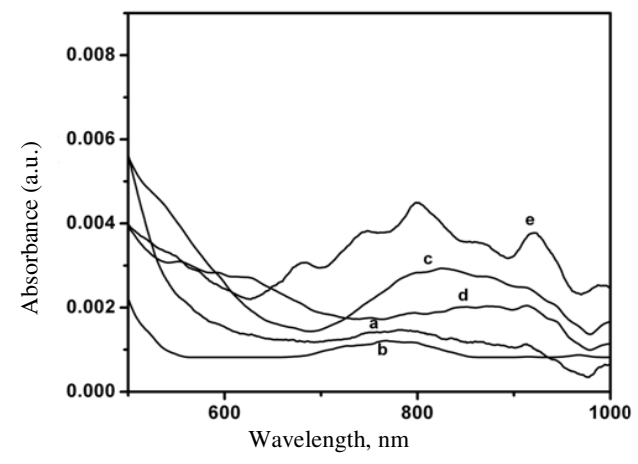

Figure 2. Electronic spectra of (a) $\left[\mathrm{NiL}^{1}\left(\mathrm{ClO}_{4}\right)\right]$; (b) $\left[\mathrm{NiL}^{2}\right]$; (c) $\left[\mathrm{NiL}^{3}\right]$; (d) $\left[\mathrm{NiL}^{4}\right]$ and $(\mathrm{e})\left[\mathrm{NiL}^{5}\right]$

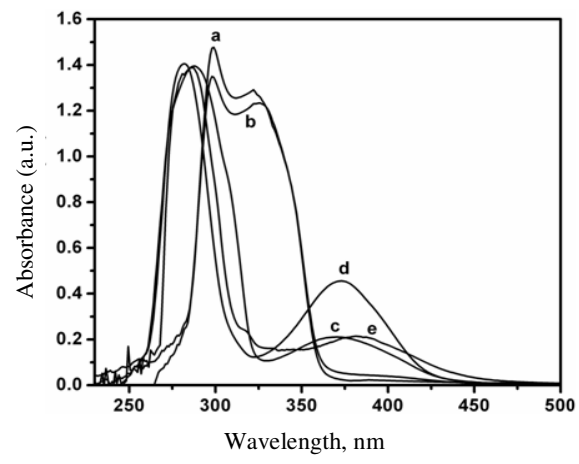

Figure 3. Electronic spectra of (a) $\left[\mathrm{NiL}^{1}\left(\mathrm{ClO}_{4}\right)\right]$; (b) $\left[\mathrm{NiL}^{2}\right]$; (c) $\left[\mathrm{NiL}^{3}\right]$; (d) $\left[\mathrm{NiL}^{4}\right]$ and $(\mathrm{e})\left[\mathrm{NiL}^{5}\right]$ 


\section{Electrochemistry of the nickel(II) complexes}

\section{Reduction process at negative potential}

The electrochemical behavior of $[\mathrm{Ni}(\mathrm{II}) \mathrm{L}]$ complexesare given in Figure 4 . The reduction potential shifts towards anodic direction for the complexes $\left[\mathrm{Ni}(\mathrm{II}) \mathrm{L}^{1}\left(\mathrm{ClO}_{4}\right)\right]$ to $\left[\mathrm{Ni}(\mathrm{II}) \mathrm{L}^{5}\right]$ from $-1.23 \mathrm{~V}$ to $-0.90 \mathrm{~V}$, as the number of methylene groups increases. This shows that, as the number of methylene groups between the imine nitrogen (chain length) increases, the entire acyclic ring becomes more flexible, which causes a distortion of the geometry of the nickel(II) complexes and makes the system more flexible, which stabilizes the low valent $\mathrm{Ni}(\mathrm{I})$.

\section{Oxidation process at positive potential}

The oxidation potential shifts towards cathodic direction for the complexes $\left[\mathrm{Ni}(\mathrm{II}) \mathrm{L}^{1}\right]$ to [Ni(II) $\left.\mathrm{L}^{5}\right]$ from $0.45 \mathrm{~V}$ to $0.68 \mathrm{~V}$ as the number of methylene group is increased. The cyclic voltammograms are given in Figure 5. This is because, as the ring size increases the flexibility and the planarity of the complexes decreases and the electrochemical oxidation process occurs with difficult.

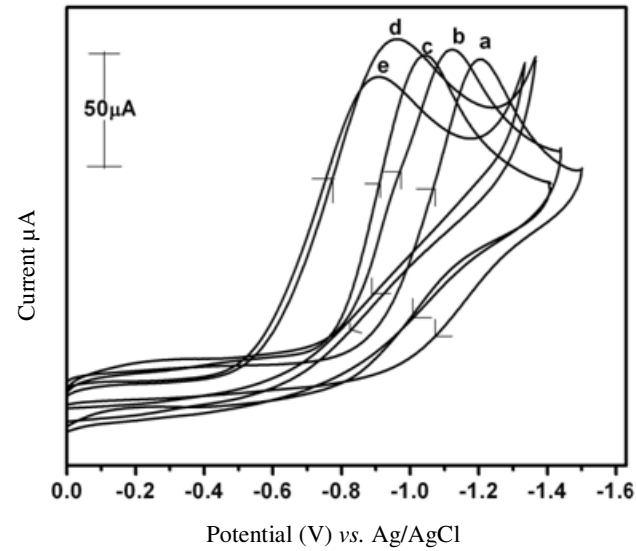

Figure 4. Cyclic voltammogram of (a) $\left[\mathrm{NiL}^{1}\left(\mathrm{ClO}_{4}\right)\right]$; (b) $\left[\mathrm{NiL}^{2}\right] ;$ (c) $\left[\mathrm{NiL}^{3}\right] ;$ (d) $\left[\mathrm{NiL}^{4}\right]$ and $(\mathrm{e})\left[\mathrm{NiL}^{5}\right]$.

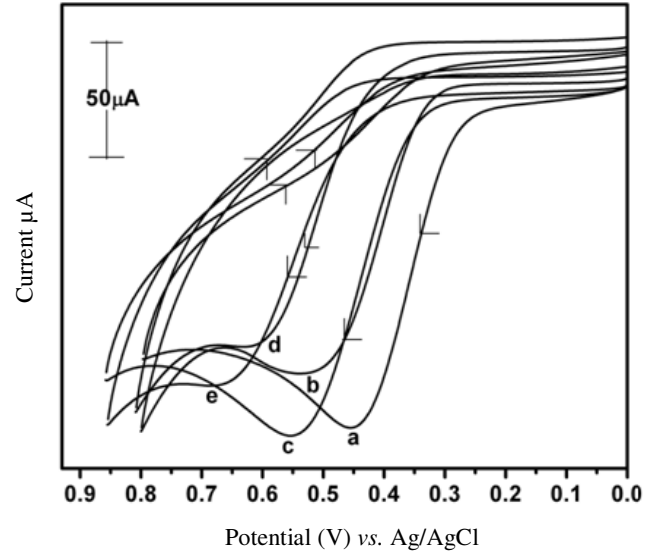

Figure 5. Cyclic voltammogram of (a) $\left[\mathrm{NiL}^{1}\left(\mathrm{ClO}_{4}\right)\right]$; (b) $\left[\mathrm{NiL}^{2}\right]$; (c) $\left[\mathrm{NiL}^{3}\right]$; (d) $\left[\mathrm{NiL}^{4}\right]$ and $(\mathrm{e})\left[\mathrm{NiL}^{5}\right]$.

Table 2. Electrochemical data and rate constant for hydrolysis of 4-nitrophenylphosphate for $\left[\mathrm{Ni}(\mathrm{II}) \mathrm{L}^{1-5}\right]$ complexes

\begin{tabular}{ccccc}
\hline No & Complexes & $\begin{array}{c}{ }^{\mathrm{a}} \text { Reduction } \\
(\text { at cathodic) } \\
(\text { V) Potential }\end{array}$ & $\begin{array}{c}{ }^{\mathrm{a}} \text { Oxidation } \\
\text { (at anodic) } \\
(\text { V) Potential }\end{array}$ & $\begin{array}{c}{ }^{\mathrm{b}} \text { Rate constant }(\mathrm{k}) \\
\times 10^{-3} \mathrm{~min}^{-1} \mathrm{NPP}\end{array}$ \\
\hline 1 & {$\left[\mathrm{Ni}(\mathrm{II}) \mathrm{L}^{1}(\mathrm{ClO})_{4}\right]$} & -1.23 & 0.45 & 1.85 \\
2 & {$\left[\mathrm{Ni}(\mathrm{II}) \mathrm{L}^{2}\right]$} & -1.13 & 0.53 & 2.84 \\
3 & {$\left[\mathrm{Ni}(\mathrm{II}) \mathrm{L}^{3}\right]$} & -1.05 & 0.55 & 4.39 \\
4 & {$\left[\mathrm{Ni}(\mathrm{II}) \mathrm{L}_{4}\right]$} & -0.95 & 0.60 & 6.86 \\
5 & {$\left[\mathrm{Ni}(\mathrm{II}) \mathrm{L}^{5}\right]$} & -0.90 & 0.68 & 8.37 \\
\hline
\end{tabular}

${ }^{a}$ Measured by $\mathrm{CV}$ at $50 \mathrm{mv} / \mathrm{s}$. Evs $\mathrm{Ag} / \mathrm{AgCl}$; Condition: $\mathrm{GC}$ working electrode and $\mathrm{Ag} / \mathrm{AgCl}$ Reference electrode: supporting electrolyte TBAP, concentration of complexes $1 \times 10^{-1} \mathrm{M}$.

${ }^{b}$ Measured spectrophotometrically in DMF, concentration of the complexes: $1 \times 10^{-3} \mathrm{M}$ 


\section{Kinetic studies of hydrolysis of 4-nitrophenylphosphate}

The catalytic activity of the nickel(II) complexes on thehydrolysis of 4-nitrophenylphosphate was determined spectrophotometrically by monitoring the increase in the characteristicabsorbance of the 4-nitrophenolate anion at420 $\mathrm{nm}$ over the time in dimethylformamide at $25{ }^{\circ} \mathrm{C}$. For this purpose, $10^{-3} \mathrm{~mol} \mathrm{dm}^{-3}$ solutions of complexes in dimethylformamide were treated with 100 equivalents of 4-nitrophenyl phosphate in the presence of air. The course of the reaction was followed at $420 \mathrm{~nm}$ regular time intervals (40 min.). The slope was determined by the method of initial rates by monitoring the growth of the $420 \mathrm{~nm}$ band of the product 4-nitrophenolate anion. A linear relationship for all the complexes shows a first-order dependence on the complex concentration for the systems. Plots of $\log \left(\mathrm{A}_{\infty} / \mathrm{A}_{\infty}-\mathrm{A}_{\mathrm{t}}\right)$ versus time for hydrolysis of 4-nitrophenylphosphate activity of the complexes are obtained and shown in Figure 6. The inset in Figure 6 shows the time dependent growth of $p$-nitrophenolate chromophore in the presence of $\left[\mathrm{Ni}(\mathrm{II}) \mathrm{L}^{5}\right]$. The catalytic activities of the nickel(II) complexes are founded to increase as the chain length increases due to the flexibility resulting from the distraction of the coordination sphere, i.e. increasing in the chain length enhances the rate constant of hydrolysis fairly well by producing distortion in the geometry around the metal ion that enhances the accessibility of the metal ion for the bonding of phosphate and $\mathrm{OH}$ group ${ }^{15}$. The rate constant value for the mononuclear nickel(II) complex $\left[\mathrm{Ni}(\mathrm{II}) \mathrm{L}^{5}\right]$ is higher $\left(8.37 \times 10^{-3} \mathrm{~min}^{-1}\right)$ than that of the complex $\left[\mathrm{Ni}(\mathrm{II}) \mathrm{L}^{4}\right]\left(6.86 \times 10^{-3} \mathrm{~min}^{-1}\right)$ which in turn is higher than the nickel(II) complex $\left[\mathrm{Ni}(\mathrm{II}) \mathrm{L}^{1}\right]\left(1.85 \times 10^{-3} \mathrm{~min}^{-1}\right)$.

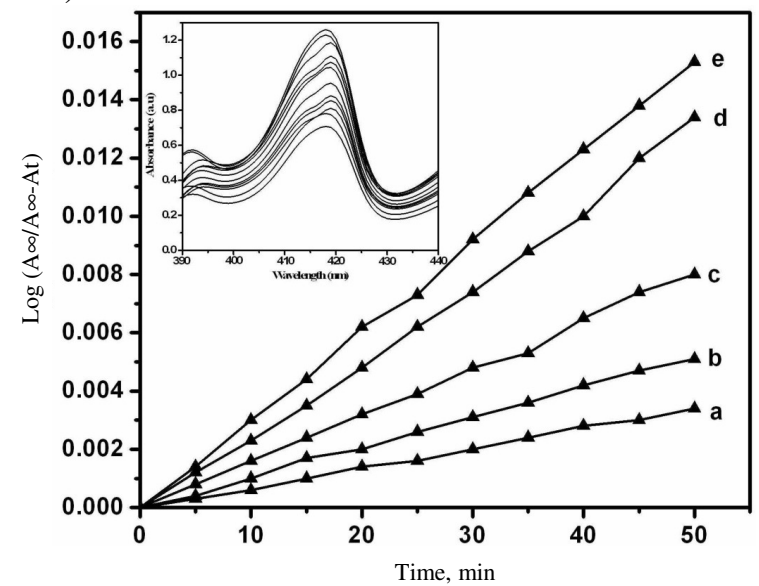

Figure 6. Hydrolysis of 4-nitrophenylphosphate by (a) $\left[\mathrm{NiL}^{1}\left(\mathrm{ClO}_{4}\right)\right]$; (b) $\left[\mathrm{NiL}^{2}\right]$; (c) $\left[\mathrm{NiL}^{3}\right]$; (d) $\left[\mathrm{NiL}^{4}\right]$ and (e) $\left[\mathrm{NiL}^{5}\right]$ The inset is the time dependent growth of $p$-nitrophenolate chromophore in the presence of $\left[\mathrm{NiL}^{5}\right]$

\section{Antimicrobial activity}

Antimicrobial activity of synthesized nickel(II) complexes against five tested microorganisms has been studied. As per the recorded data all the mono nuclear compounds showed different effects against the different organisms. The nickel(II) complexes showing highest activity against Salmonellaq typhii and at the concentration of $125 \mu \mathrm{M}$. Complex $\left[\mathrm{Ni}(\mathrm{II}) \mathrm{L}^{5}\right]$ has the highest antimicrobial activity against all the organisms, in contrast $\left[\mathrm{Ni}(\mathrm{II}) \mathrm{L}^{2}\right]$ showed the lowest activity. This difference in inhibition may be due to the differences between the cell structures of bacteria, yeast and not depend upon the number of 
alkyl group present in the complex. While the cell walls of fungi contain chitin, the cell walls of bacteria contain murein ${ }^{16}$. In addition, fungi contain ergosterol in their cell membranes instead of the cholesterol found in the cell membranes of animals ${ }^{17}$. In addition, the difference in the antibacterial activity nickel(II) complexes studied in this work.

\section{Conclusion}

In conclusion, five Schiff base nickel(II) complexes have been synthesized and their coordination chemistry and antibacterial activity have been investigated. The electronic spectra of $\left[\mathrm{Ni}(\mathrm{II}) \mathrm{L}^{1-5}\right]$ complexes indicates square planar geometry and there is a red shift due to the increase in the chain length. Cyclic voltammograms exhibit one electron quasi-reversible process. The reduction potential shifts to more negative potential on increasing chain length and oxidation potential shifts more positive potential on increasing chain length. All the $\left[\mathrm{Ni}(\mathrm{II}) \mathrm{L}^{1-5}\right]$ complexes show good catalytic activity on increasing the chain length. Increase in the chain length causes a greater distortion of the geometry of the complexes. This flexibility in the geometry may favour the observed higher rate of the reaction. The nickel(II) complexes showing highest activity against Salmonellaq typhii and at the concentration of $125 \mu \mathrm{M}$. Complex $\left[\mathrm{Ni}(\mathrm{II}) \mathrm{L}^{5}\right]$ has the highest antimicrobial activity against all the organisms, All these studies of the complexes agree well with the established trend.

\section{Reference}

1. Adams H, Bucknal R M, Fenton D E, Rodríguez C O, García M and Oakes J, Polyhedron, 1998, 17(21), 3803-3808.

2. Hernandez Molina R and Mederos A, In Comprehensive Coordination Chemistry II, Ed., Lever A B P, Elsevier-Pergamon Press: New York, 2003, 1, 411.

3. Mueller K and Schert U, Organic Light Emitting Devices; Wiley-WCH: New York, 2006.

4. Hadson S A and Maitlis P V, Chem Rev., 1993, 93, 861

5. $\quad$ Burdette S C and Lippard S J, Coord Chem Rev., 2001, 216, 333-361.

6. (a) Che C M and Huang J S, Coord Chem Rev., 2003, 242, 97-113; (b) Venkataraman N S, Kuppuraj G and Rajagopal S, Coord Chem Rev., 2005, 249, 1249.

7. Saleh A A, J Coord Chem., 2005, 58, 255.

8. Thauer R K, Diekert G and Schonheit P, Trends Biochem Sci., 1980, 5, 304.

9. (a) Halcrow M A and Christou G, Chem Rev., 1994, 94, 2421-2481; (b) Kolodziej A F, Prog Inorg Chem., 1994, 41, 493.

10. EI-Metwally N M, Gabr I M, Shallaby A M and EI-Asmy A A, J Coord Chem., 2005, $\mathbf{5 8}, 1154$.

11. Kaloyanov N, Neykor M, Wesselinova D W and Dimiltrov G D, Cent Eur J Chem., 2012, 10, 1034.

12. Nakamoto K, Infrared Spectra of Inorganic and Coordination Compounds; John Willey and Sons: New York, 1986, 244.

13. Raman N, Dhaveethu R J, Sakthivel A and Chil J, Chem Soc., 2008, 53(3), 1568-1571.

14. Bottcher A, Elias H, Jager E G, Langfelderova H, Mazur M, Muller L, Paulus H, P. Pelikan P, Rudolph M and Valko M, Inorg Chem.,.1993, 32, 4131-4138.

15. Vijayaraj A, Prabu R, Suresh R, Jayanthi G, Muthumary J and Narayanan V, Synthesis and Reactivity in Inorganic, Metal-Organic and Nano-Metal Chem., 2011, 41(8), 963-972.

16. Eweis M, Elkholy S.S and Elsabee M Z, Int J Biol Macromol., 2006, 38, 1-8.

17. Fleet G H, Composition and Structure of Yeast Cell Walls Current Topics in Medical Mycology, Springer-Verlag: New York USA, Vol 1, 1985. 